\author{
Konrad Żak \\ ORCID: 0000-0002-2632-9782 \\ Pharma Consulting \\ KonZak@interia.pl
}

\title{
Opieka farmaceutyczna czy profesjonalne doradztwo? Bariery wdrażania opieki farmaceutycznej w Polsce
}

Artykuł nadesłany: 26 maja 2018 r.; artykuł zaakceptowany: 1 września 2018 r.

JEL Classification: I14, I18, K32

Keywords: pharmacy, pharmaceutical services, pharmaceutical law

\section{Abstract \\ Pharmaceutical care or professional advice? Barriers to the implementation of pharmaceutical care in Poland}

The provision of pharmaceutical services in a public pharmacy is related to the performance of a series of specialized activities aimed at the realization of the basic mission of the pharmacy, which is the protection of public health. Pharmaceutical care, included in the catalog of pharmaceutical services, is part of the pro-social system of achieving the objectives and tasks of a retail pharmacy. However, its implementation in pharmacy practice encounters a number of obstacles and barriers. Barriers to the implementation of pharmaceutical care result primarily from a lack of precise and understandable for all participants (doctors, patients and pharmacists) legal regulations controlling the basic principles of cooperation. They are a derivative of the lack of vision and the definition of the functions that pharmaceutical care should perform in the process of managing pharmacotherapy. This article presents the essence of pharmaceutical care in the process of managing the pharmacotherapy of the patient and indicates the difference between its effective implementation and the realization of the professional advisory process in a public pharmacy. The conclusions and recommendations contained therein were formulated and presented on the basis of the results of an empirical study. 


\section{Wstęp}

Opieka farmaceutyczna, rozumiana jako kooperacja pomiędzy lekarzem, pacjentem i farmaceutą, do systemu polskiego prawa farmaceutycznego została wprowadzona dopiero w 2008 roku na mocy nowelizacji ustawy o izbach aptekarskich (ustawa o zmianie ustawy o izbach aptekarskich, 2008, art. 1 ust. 2). Od tego momentu opieka farmaceutyczna stanowi prawnie usankcjonowaną usługę farmaceutyczną polegającą

na dokumentowanym procesie, w którym farmaceuta, współpracując z pacjentem i lekarzem, a $\mathrm{w}$ razie potrzeby z przedstawicielami innych zawodów medycznych, czuwa nad prawidłowym przebiegiem farmakoterapii w celu uzyskania określonych jej efektów poprawiających jakość życia pacjenta. (ustawa o izbach aptekarskich, 1991, art. 2a ust. 1, pkt 7)

Pomimo jasno ustalonej definicji ustawodawca nie określił w systemie prawa farmaceutycznego szczegółowych przepisów wykonawczych, które mogłyby urzeczywistnić opiekę farmaceutyczną w praktyce aptecznej.

Brak zdefiniowania i rozgraniczenia celów, zadań, zakresów obowiązków i odpowiedzialności poszczególnych podmiotów (przedstawicieli zawodów medycznych) oraz sposobów gromadzenia, przetwarzania, przekazywania i zabezpieczenia informacji (danych pacjentów) stanowi podstawową barierę implementacji opieki farmaceutycznej w praktyce aptecznej. Zasadniczo poza dołączeniem opieki farmaceutycznej do katalogu usług farmaceutycznych i lakonicznym określeniu definicji ustawodawca nie wskazał żadnych istotnych regulacji, które normowałyby jej realizację w aptece ogólnodostępnej (Żak, 2017, s. 84). Brak szczegółowych wskazań prawnych w praktyce uniemożliwia profesjonalne podejście do opieki farmaceutycznej, ponieważ współdziałanie na linii lekarz-pacjent-farmaceuta wymaga jednoznacznego i niebudzącego wątpliwości zdefiniowania celów, określenia zakresu zadań poszczególnych podmiotów oraz rozgraniczenia odpowiedzialności. Niejasność sytuacji wyjściowej oraz nieprecyzyjność i niejednoznaczność polskiego prawa farmaceutycznego wywołują obawy i niechęć środowiska farmaceutów do opieki farmaceutycznej. Racjonalizacja przepisów prawa oraz eliminacja obaw personelu aptecznego pozwoli na przekształcenie profesjonalnego doradztwa w korzystny dla systemu ochrony zdrowia publicznego proces opieki farmaceutycznej.

\section{Informacja jako podstawowy aspekt profesjonalnego doradztwa}

Specyfika procesu świadczenia usług farmaceutycznych wymaga podejmowania decyzji w ramach szczególnych kompetencji farmaceuty na bazie jego wiedzy i doświadczenia. Udzielanie informacji i porad dotyczących działania i stosowa- 
nia produktów leczniczych i wyrobów medycznych będących przedmiotem obrotu w aptekach, w myśl zapisów ustawy o izbach aptekarskich stanowi usługę farmaceutyczną (ustawa o izbach aptekarskich, 1991, art. 2a ust. 1 pkt 6). Prowadzenie profesjonalnego doradztwa $\mathrm{w}$ aptece ogólnodostępnej opiera się na posiadaniu informacji dotyczących stanu zdrowia pacjenta, rodzaju zażywanych leków i sposobu ich przyjmowania. Posiadanie przedmiotowych informacji minimalizuje prawdopodobieństwo podjęcia przez farmaceutę błędnych decyzji i pozwala na bezpieczne dla pacjenta zarządzanie jego farmakoterapią.

Informacje o stanie zdrowia pacjenta i przyjmowanych przez niego lekach stanowią zasób strategiczny apteki, wykorzystywany przez jej personel w bieżącej działalności operacyjnej, albowiem wiedza pozyskana dzięki nim decyduje o skuteczności procesu farmakoterapii. Obecnie na aptecznym rynku farmaceutycznym informacja stanowi źródło wiedzy o wciąż nie do końca odkrytym potencjale z uwagi na trudności w określeniu poziomu jej jakości. Rzetelna, aktualna i właściwie zinterpretowana informacja może stanowić źródło przewagi konkurencyjnej, ponieważ pozwala na podejmowanie skuteczniejszych i trafniejszych decyzji.

Zdobywanie informacji zostało wplecione w zakres obsługi na etapie rozpoznania potrzeb pacjenta i powoli ulega procesowi standaryzacji. Podczas wywiadu z pacjentem farmaceuta może stosować pytania otwarte, wykorzystując podstawowe operatory: „co”, „czy”, ,gdzie”, ,jak”, ,jaki”, „kiedy” („od kiedy”), „kto” jako źródło przybliżające do zdobycia większej ilości informacji. Wskazanym rozwiązaniem jest zadanie pacjentowi trzech podstawowych pytań: ,jak Pani opisałaby ten ból?”, ,jak często to się Pani zdarza?”, „czy przyjmuje Pani inne leki?” lub „od jak dawna odczuwa Pan tę dolegliwość?”, ,jakie inne problemy Pan miewał?”, „,zy jest Pan na coś uczulony?”. Należy przy tym zauważyć, że pacjent nie zawsze jest w stanie rzetelnie i zrozumiale przedstawić swój problem zdrowotny. Żeby zawęzić pacjentowi możliwość odpowiedzi (do odpowiedzi „tak” lub „nie”), można zastosować pytania zamknięte: „czy ma Pan podwyższoną temperaturę?”, „czy ma Pan katar?”, „czy katar, o którym Pani mówi, jest związany z alergią, czy przeziębieniem?” itp.

W przypadku realizacji recepty farmaceuta zyskuje dodatkowe źródło wiedzy o stanie zdrowia pacjenta, jakim jest lekarz. Informacje pozyskane bezpośrednio od lekarza mają najwyższy walor rzetelności, ponieważ to lekarz jest osobą prowadzącą farmakoterapię pacjenta. Analiza informacji zamieszczonych na recepcie wzbogaca dane na temat procesu farmakoterapii pacjenta, zebrane przez farmaceutę w toku pracy w aptece. Im więcej źródeł informacji może wykorzystać farmaceuta do celów profesjonalnego doradztwa, tym lepiej dla pacjenta. Problemem może być właściwe zarządzanie zdobytymi informacjami, które wymaga odpowiedniego systemu gromadzenia i przetwarzania danych.

Pozyskanie informacji od pacjenta pozwala na jednorazowe rozwiązanie jego problemu zdrowotnego, lecz nie umożliwia właściwego zarządzania jego farmakoterapią. Do tego potrzebne są rozwiązania zapewniające gromadzenie, przetwa- 
rzanie i analizę informacji w celu wykrycia i rozwiązania problemów lekowych i terapeutycznych. Od tego momentu profesjonalne doradztwo ulega transformacji w proces opieki farmaceutycznej.

\section{Opieka farmaceutyczna jako usługa farmaceutyczna - aspekt prawny i ekonomiczny}

Pomimo iż opieka farmaceutyczna w systemie prawa farmaceutycznego funkcjonuje od 2008 roku, to ustawodawca nie stworzył dotąd (2018 rok) szczegółowych przepisów wykonawczych, które precyzowałyby cele, zadania, zakresy obowiązków farmaceuty i przedstawicieli zawodów medycznych zaangażowanych w realizację procesu farmakoterapii pacjenta. Dotychczas nie stworzono jasnego i precyzyjnego systemu zarządzania pozyskanymi, zgromadzonymi i przetworzonymi informacjami (danymi na temat stanu zdrowia pacjenta oraz rodzaju zażywanych leków i sposobu ich przyjmowania), jak również systemu zabezpieczenia danych osobowych. Utrudnia to sprawowanie opieki farmaceutycznej, która oparta na płaszczyźnie współpracy trzech podmiotów: lekarza, pacjenta i farmaceuty wymaga jednoznacznych oraz ścisłych i niebudzących wątpliwości regulacji (Żak, 2017, s. 87).

Definicja opieki farmaceutycznej zawarta w ustawie o izbach aptekarskich wskazuje na dwa podstawowe jej aspekty:

— ciągłość (systematyczność) — „czuwa nad prawidłowym przebiegiem farmakoterapii w celu uzyskania określonych jej efektów poprawiających jakość życia pacjenta",

— formalizacja — sprawowanie opieki farmaceutycznej polega „na dokumentowanym procesie".

Zatem opieka farmaceutyczna polega na

prowadzeniu, na podstawie uzyskanych od pacjenta danych dotyczących jego stanu zdrowia i opracowanego indywidualnego planu opieki, systematycznych i kompleksowych działań zmierzających do osiągnięcia zaplanowanych celów w zakresie poprawy jakości życia pacjenta, realizowanych przede wszystkim poprzez systematyczne monitorowanie zaordynowanej przez lekarza farmakoterapii oraz systematyczne działania edukacyjne, w ścisłej koordynacji działań farmaceuty z działaniami lekarza prowadzącego terapię pacjenta. (Adamczyk, 2016, s. 260)

Tak sformułowane określenia charakteryzujące opiekę farmaceutyczną wskazują na konieczność opracowania i implementacji systemu zarządzania danymi osobowymi pacjenta, co nakłada na farmaceutę dodatkowe obowiązki związane z pozyskiwaniem, gromadzeniem i przetwarzaniem informacji. Co ciekawe, do celów ochrony stanu zdrowia, świadczenia usług medycznych lub leczenia pacjentów przez osoby trudniące się zawodowo leczeniem lub świadczeniem innych usług medycznych zarządzanie udzielaniem usług medycznych, przetwarzanie 
danych jest na mocy prawa dopuszczalne pod warunkiem, że są stworzone pełne gwarancje ochrony danych osobowych (ustawa o ochronie danych osobowych, Dz.U. 1997, art. 27 ust. 2 pkt 7) $)^{1}$. Należy przy tym zauważyć, że opieka farmaceutyczna formalnie została zakwalifikowana do katalogu usług farmaceutycznych, w myśl zaś zapisów ustawy o ochronie danych osobowych dopuszczalność przetwarzania danych odnosi się bezpośrednio do usług medycznych. Może to rodzić poważne wątpliwości prawne w stosunku do podejmowanych działań związanych z zarządzaniem danymi osobowymi pacjenta, dlatego wskazane jest uzyskanie w tym zakresie wyraźnej zgody pacjenta.

Występowanie legalnej definicji opieki farmaceutycznej w systemie prawa farmaceutycznego nie rozwiewa wątpliwości dotyczących jej implementacji w praktyce aptecznej. Brak odpowiednich przepisów wykonawczych utrudniawłaściwe sprawowanie opieki farmaceutycznej, wprowadzając do aptek element niepewności. Główny Inspektor Farmaceutyczny próbuje je rozwiewać wskazując, że ustawodawca nakładając obowiązek sprawowania opieki farmaceutycznej, miał na celu takie działania, jak udzielanie informacji o leku, jego dawkowaniu, możliwych działaniach niepożądanych oraz konsultacje farmaceuty z lekarzem (komunikat nr 2/2013 Głównego Inspektora Farmaceutycznego, 2013, s. 2). Jednak takie działania, choć zmierzają w dobrym kierunku, nie mogą stanowić wystarczającej przesłanki przy definiowaniu zakresu, charakteru i przebiegu procesów opieki farmaceutycznej. Konieczne w tym zakresie jest wprowadzenie systemowych uregulowań uwzględniających specyfikę podstawowych programów leczenia dolegliwości pacjenta.

Dokonując analizy otoczenia politycznoprawnego apteki, należy zauważyć, że odpowiednie umiejscowienie opieki farmaceutycznej w systemie prawa farmaceutycznego może przynieść wymierne korzyści, ponieważ w perspektywie długookresowej może znacząco przyczynić się do poprawy stanu zdrowia i jakości życia pacjenta, a co za tym idzie wpłynąć na obniżenie kosztów jego farmakoterapii. Przekłada się to bezpośrednio na niższe koszty polityki refundacyjnej państwa. Zdrowszy pacjent rzadziej korzysta z systemu opieki zdrowotnej, co oznacza niższe koszty i większą dostępność usług medycznych. Właściwie spra-

${ }^{1}$ Podobnie według przepisów rozporządzenia Parlamentu Europejskiego i Rady (UE) przetwarzanie danych osobowych jest dopuszczalne do celów profilaktyki zdrowotnej lub medycyny pracy, do oceny zdolności pracownika do pracy, diagnozy medycznej, zapewnienia opieki zdrowotnej lub zabezpieczenia społecznego, leczenia lub zarządzania systemami i usługami opieki zdrowotnej lub zabezpieczenia społecznego na podstawie prawa Unii lub prawa państwa członkowskiego lub zgodnie z umową z pracownikiem służby zdrowia, jeżeli są przetwarzane przez — lub na odpowiedzialność — pracownika podlegającego obowiązkowi zachowania tajemnicy zawodowej na mocy prawa Unii lub prawa państwa członkowskiego, lub przepisów ustanowionych przez właściwe organy krajowe lub przez inną osobę również podlegającą obowiązkowi zachowania tajemnicy zawodowej na mocy prawa Unii lub prawa państwa członkowskiego, lub przepisów ustanowionych przez właściwe organy krajowe (rozporządzenie Parlamentu Europejskiego i Rady, 2016, art. 9 ust. 2h, ust. 3). 
wowana opieka farmaceutyczna może również stanowić źródło przewagi konkurencyjnej apteki, pozwalając na osiągnięcie następujących korzyści:

- wzrost znaczenia apteki i jej pozycji w systemie ochrony zdrowia publicznego jako placówki zorientowanej na klienta (przedkładającej dobro pacjenta ponad wszystko) w wyniku optymalizacji procesu farmakoterapii pacjenta mającej na celu uniknięcie niepożądanych interakcji lekowych oraz minimalizację marnotrawstwa produktów leczniczych;

- poprawa pozycji rynkowej oraz zdolności konkurencyjnych apteki poprzez wzrost poziomu lojalności i satysfakcji pacjentów wynikający z preferowania przez nich tych aptek, w których dostępne są usługi związane z zarządzaniem ich terapią farmakologiczną (Brooks et al., 2007, s. 4-27);

- wzrost znaczenia apteki w relacjach $\mathrm{z}$ lekarzami i przedstawicielami innych zawodów medycznych, co znacznie zwiększa szanse osiągnięcia sukcesu ekonomicznego (Scharitzer i Kollarits, 2000, s. 955-965);

- wzrost zadowolenia farmaceutów z wykonywanej pracy, wynikający z rosnącego prestiżu zawodu aptekarza i podniesienia jego rangi w realizacji społecznej misji apteki (Łazowski, 2005a, s. 95; Skowron, 2008, s. 6).

Przedstawione korzyści mogą przełożyć się w sposób wymierny na wzrost przychodów ze sprzedaży apteki poprzez zwiększenie liczby stałych klientów, bardziej lojalnych i zadowolonych z jakości usług apteki. W wypadku gdy opieka farmaceutyczna przynosi pacjentom odczuwalne efekty i jest sprawowana w sposób lepszy, niż czyni to konkurencja, to apteka może pozyskać nowych klientów. Należy przy tym zauważyć, że w obecnej sytuacji rynkowej pozyskanie nowych klientów odbywa się zazwyczaj w wyniku ich przejęcia od podmiotów konkurencyjnych. Zatem do poprawy pozycji konkurencyjnej sama implementacja opieki farmaceutycznej w praktyce aptecznej może nie wystarczyć, ponieważ dla pacjenta istotna jest również jakość sprawowanej opieki farmaceutycznej, która powinna generować wymierne efekty i wpływać co najmniej na poprawę jego stanu zdrowia (bez konieczności ponoszenia przez pacjenta dodatkowych kosztów).

\section{Opieka farmaceutyczna w Polsce}

Implementacja opieki farmaceutycznej do systemu prawa farmaceutycznego nastąpiła w wyniku starań akademickich środowisk farmaceutycznych ośrodków w Warszawie, Poznaniu, Krakowie, Gdańsku i Wrocławiu (Szalonka, 2011, s. 65$)^{2}$. Efektem przedmiotowych zabiegów było opracowanie strategii wdrażania opieki farmaceutycznej w Polsce, kategoryzujących wiele celów działania (Marczak, 2007, s. 2):

2 Duże zasługi w propagowaniu idei opieki farmaceutycznej i podejmowaniu działań zmierzających do jej wdrożenia w praktyce aptecznej przypisuje się J. Łazowskiemu, A. Skowron, zespołowi J. Brandysa i T. Bąbelkowi (Szalonka, 2011, s. 65). 
1. Wydawanie produktów leczniczych

- wydawanie produktów leczniczych i/lub wyrobów medycznych w optymalnych warunkach i w zgodzie z obowiązującym prawem, lekowych.

- wykrywanie i rozwiązywanie rzeczywistych i potencjalnych problemów

2. Konsultacje i poradnictwo farmaceutyczne

- instruowanie pacjenta $\mathrm{w}$ zakresie optymalnego rozwiązywania jego problemów zdrowotnych wraz z wyborem najodpowiedniejszego produktu leczniczego, jeżeli to możliwe,

— rozstrzyganie wątpliwości, jakie pojawią się u pacjenta, lub uzupełnianie niedoborów informacji, stwierdzonych przez farmaceutę,

- ochrona pacjenta przed problemami lekowymi,

— ocena sytuacji, czy dany problem zdrowotny jest konsekwencją jakiegoś problemu lekowego.

3. Ocena i monitorowanie farmakoterapii

— dążenie do uzyskania maksymalnej efektywności leczenia farmakologicznego,

— minimalizacja zagrożeń związanych ze stosowaniem produktu leczniczego, przyczyniająca się do zwiększonego bezpieczeństwa farmakoterapii,

— racjonalizacja stosowania produktów leczniczych stanowiących zasadnicze narzędzie terapeutyczne,

— polepszenia jakości życia pacjenta.

Wielopoziomowość celów wskazuje, że opieka farmaceutyczna wymaga podejścia procesowego z uwagi na konieczność realizacji wieloetapowych, następujących po sobie działań (Skowron, 2005, s. 3-13):

- etap 1: nawiązanie profesjonalnych relacji z pacjentem,

- etap 2: zebranie informacji dotyczących stanu zdrowia pacjenta,

- etap 3: wykrycie problemów lekowych,

- etap 4: rozwiązanie problemów lekowych,

- etap 5: określenie celów terapeutycznych,

- etap 6: wskazanie dostępnych alternatyw terapeutycznych,

— etap 7: wybór najlepszego rozwiązania terapeutycznego,

— etap 8: opracowanie i wdrożenie planu opieki farmaceutycznej,

— etap 9: kontynuacja opieki i ocena uzyskanych efektów.

Istotnym wsparciem implementacji opieki farmaceutycznej w praktyce aptecznej może być prowadzony od 2009 roku program naukowo-szkoleniowy FONTiC, będący kontynuacją i rozszerzeniem projektu „Farmaceutyczna Opieka w Nadciśnieniu Tętniczym i Cukrzycy”, dający możliwość (Skowron et al., 2010, s. 394):

- bezpiecznego gromadzenia danych pacjentów objętych opieką farmaceutyczną,

- przygotowywania automatycznych raportów umożliwiających farmaceutom ocenę skuteczności farmakoterapii i opieki farmaceutycznej, 
— oceny jakości życia pacjentów przy pomocy zwalidowanych kwestionariuszy ogólnych,

- oceny wiedzy pacjentów przy pomocy specjalistycznych kwestionariuszy,

- monitorowania farmakoterapii dzięki gromadzeniu informacji o wartościach wybranych parametrów klinicznych,

- przygotowania, analizowania i poprawiania planu opieki farmaceutycznej,

- przygotowania planu edukacji pacjenta.

Aplikacja FONTiC została zaprojektowana jako usługa sieciowa dostępna z poziomu dowolnej przeglądarki internetowej, umożliwiając centralizację baz danych, udostępnienie aplikacji oraz możliwość bieżącej analizy danych, bez potrzeby tworzenia dodatkowego kanału ich dystrybucji pomiędzy farmaceutami a jednostką naukowobadawczą. Jest zgodna z wymogami prawa w zakresie ochrony danych osobowych pacjenta, a modułowa konstrukcja bazy umożliwia tworzenie dowolnych konfiguracji w zakresie uprawnień do korzystania $\mathrm{z}$ poszczególnych elementów. Uwzględniając ograniczenia dotyczące zasad gromadzenia i przetwarzania informacji, wynikające z zapisów ustawy o ochronie danych osobowych, należy wskazać, że rodzaj udostępnianych danych w bazie jest maksymalnie ograniczany i zależy od roli danego użytkownika w programie FONTiC $^{3}$ (Skowron et al., 2010, s. 394-395).

Pomimo przedmiotowych udogodnień należy zauważyć, że opieka farmaceutyczna w polskich realiach prawno-ekonomicznych nie wygląda imponująco. Według badań przeprowadzonych przez K. Szalonkę w 2010 roku 23\% farmaceutów i techników farmaceutycznych deklarowało świadczenie opieki farmaceutycznej w rozumieniu ustawy $(\mathrm{N}=114)$, przy zainteresowaniu usługą $67 \%$ pacjentów $(\mathrm{N}=112)$ (Szalonka, 2011, s. 225, 234) ${ }^{4}$. Zważywszy, że poziom deklaracji często jest zawyżany przez uczestników badania (w tym wypadku dotyczy to farmaceutów i techników farmaceutycznych), można przyjąć, że stan faktyczny opieki farmaceutycznej jest zdecydowanie gorszy ${ }^{5}$.

${ }^{3}$ Baza FONTiC przewiduje cztery poziomy dostępu: administrator systemu, farmaceuta, lekarz oraz pacjent, $\mathrm{z}$ odpowiednimi dla każdego poziomu uprawnieniami $\mathrm{w}$ zakresie dodawania nowych informacji, podglądu i/lub poprawiania zgromadzonych danych oraz tworzenia raportów (Skowron et al., 2010, s. 395).

${ }^{4}$ Należy przy tym zauważyć, że zakres obowiązków technika farmaceutycznego, zawarty w ustawie Prawo farmaceutyczne, nie obejmuje świadczenia usługi opieki farmaceutycznej zarezerwowanej w systemie prawa farmaceutycznego wyłącznie dla farmaceuty.

5 Do programu FONTiC w latach 2009-2011 przystąpiły 34 apteki (na mniej więcej 12 tys. aptek funkcjonujących w tym okresie), co stanowi ok. 0,3\% wszystkich aptek (Żak, 2011, s. 159). 


\section{Bariery wdrożenia opieki farmaceutycznej w aptece ogólnodostępnej na podstawie wyników badania empirycznego}

Profesjonalne podejście do problemu opieki farmaceutycznej w aptece ogólnodostępnej wymaga podjęcia wielu działań dostosowawczych zarówno przez właściciela apteki (organ prowadzący aptekę), jak i personel farmaceutyczny. Część tych działań wiąże się z poniesieniem dodatkowych nakładów na przygotowanie i wyposażenie stanowiska do spotkań z pacjentem (stanowiska konsultacyjnego), a nawet z koniecznością zatrudnienia dodatkowego farmaceuty, co w praktyce może być trudne, jeżeli właściciel apteki (organ prowadzący aptekę) nie zauważy w tym wymiernych korzyści dla apteki. Po stronie farmaceuty zachodzi konieczność podjęcia dodatkowych obowiązków i zadań związanych z przygotowaniem się (doszkoleniem) do bardziej odpowiedzialnej pracy z pacjentem oraz nieodzowność poświęcenia większej ilości czasu na przeprowadzenie spotkań z pacjentem. Praktyka apteczna pokazuje, że perspektywa wprowadzenia jakichkolwiek dodatkowych działań prowadzi po powstawania barier na etapie ich wdrażania.

\subsection{Metodyka badania empirycznego}

Celem zrealizowanego badania empirycznego była identyfikacja barier wdrożenia opieki farmaceutycznej oraz wskazanie działań mających na celu usprawnienie i udogodnienie jej implementacji w praktyce aptecznej. Identyfikacja barier wdrożenia opieki farmaceutycznej w aptece pozwoli wskazać podstawowe czynniki wpływające na niechęć farmaceutów do zajęcia się problemem opieki farmaceutycznej w sposób profesjonalny oraz umożliwi odpowiedź na pytania:

— w jaki sposób farmaceuci udzielają porad pacjentom? (czym się w tym zakresie kierują?);

— jakie czynniki przeszkadzają farmaceutom we właściwym sprawowaniu opieki farmaceutycznej?;

— czy istnieje współzależność pomiędzy deklarowanym przez farmaceutów występowaniem danej bariery wdrażania opieki farmaceutycznej a posiadanym wykształceniem właściciela apteki (farmaceuta vs „nie-farmaceuta”)?;

- jakie działania mogłyby ułatwić właściwe sprawowanie opieki farmaceutycznej w aptece? (w jakich obszarach należy dokonać działań optymalizacyjnych?).

Do realizacji założeń badania empirycznego zastosowano kwestionariusz ankiety, w którym farmaceuci wyrażali opinię w dwunastu obszarach definiujących bariery wdrażania opieki farmaceutycznej w następującej skali: zdecydowanie tak, raczej tak, nie wiem, raczej nie, zdecydowanie nie (ankieta skonstruowana została według zasady: pierwszy obszar definiujący bariery implementacji opieki farmaceutycznej równa się pierwsze pytanie w kwestionariuszu). Pozyskane dane 
poddano analizie statystycznej z wykorzystaniem miary statystycznej opartej na tablicy korelacyjnej — współczynnik zbieżności korelacyjnej Cramera. Badanie przeprowadzono w miesiącach wrzesień-listopad 2017 roku na próbie 111 farmaceutów aptekarzy z województw lubelskiego, świętokrzyskiego i podkarpackiego równolegle z projektem ukierunkowanym na sprawdzenie aktualnego stanu wiedzy farmaceutów z zakresu znajomości zasad, reguł i norm zawartych w kodeksie etyki zawodowej oraz struktury i okoliczności uchwalenia Kodeksu Etyki Aptekarza Rzeczypospolitej Polskiej ${ }^{6}$.

Dobór celowo-kwotowy próby badawczej wynika z założenia dotarcia do 10\% ogółu farmaceutów pracujących w danym województwie: 180 (na 1795) w województwie lubelskim, 75 (na 753) w województwie świętokrzyskim, 129 (na 1292) w województwie podkarpackim. Charakterystyka próby badawczej: 111 farmaceutów (na 384 z próby docelowej i 3840 ogółu pracujących), co stanowi $28,9 \%$ próby docelowej i $2,9 \%$ ogółu pracujących. Charakterystyka szczegółowa z rozbiciem na poszczególne województwa: województwo lubelskie: 58 farmaceutów, co stanowi 32,2\% próby docelowej i 3,2\% ogółu zatrudnionych; województwo świętokrzyskie: 12 farmaceutów, co stanowi $16,0 \%$ próby docelowej i 1,6\% ogółu pracujących; województwo podkarpackie 41 farmaceutów, co stanowi 31,8\% próby docelowej i 3,2\% ogółu pracujących ${ }^{7}$. Strukturę właścicielską przedstawiono w tabeli 1.

Tabela 1. Struktura właścicielska

\begin{tabular}{l|c|c|c|c|c|c|c|c}
\hline \multirow{2}{*}{$\begin{array}{c}\text { Wykształcenie } \\
\text { właściciela apteki }\end{array}$} & \multicolumn{7}{|c|}{ Województwo } & \multicolumn{2}{c}{ Razem } \\
\cline { 2 - 9 } & \multicolumn{2}{|c|}{ lubelskie } & \multicolumn{1}{c}{ świętokrzyskie } & podkarpackie & \multicolumn{2}{c}{} \\
\hline & $\sum$ & $\%$ & $\sum$ & $\%$ & $\sum$ & $\%$ & $\sum$ & $\%$ \\
\hline farmaceutyczne & 28 & 25,2 & 5 & 4,5 & 18 & 16,2 & 51 & $\mathbf{4 5 , 9}$ \\
\hline inne & 30 & 27,1 & 7 & 6,3 & 23 & 20,7 & 60 & $\mathbf{5 4 , 1}$ \\
\hline razem & $\mathbf{5 8}$ & $\mathbf{5 2 , 3}$ & $\mathbf{1 2}$ & $\mathbf{1 0 , 8}$ & $\mathbf{4 1}$ & $\mathbf{3 6 , 9}$ & 111 & 100,0 \\
\hline
\end{tabular}

Źródło: opracowanie na podstawie badań własnych.

${ }^{6}$ Metodyka i wyniki badania dotyczącego sprawdzenia aktualnego stanu wiedzy farmaceutów z zakresu znajomości zasad, reguł i norm zawartych w kodeksie etyki zawodowej oraz struktury i okoliczności uchwalenia Kodeksu Etyki Aptekarza Rzeczypospolitej Polskiej zostały przedstawione na ogólnopolskiej konferencji naukowej „Przedsiębiorczość — etyka — odpowiedzialność ciągłe doskonalenie?” zrealizowanej przez Akademię Leona Koźmińskiego w Warszawie (Żak, 2018).

7 Liczba odmów w udziale w badaniu (w odniesieniu do próby docelowej): 273 farmaceutów, co stanowi $71,1 \%$ farmaceutów z próby docelowej. Rozkład ze względu na poszczególne województwa: 122 farmaceutów z województwa lubelskiego, co stanowi 67,8\% próby docelowej; 63 farmaceutów z województwa świętokrzyskiego, co stanowi 84,0\% próby docelowej; 88 farmaceutów z województwa podkarpackiego, co stanowi $68,2 \%$ grupy docelowej. Odniesienie do liczby farmaceutów na podstawie: Główny Urząd Statystyczny, 2017, s. 2. Badaniem nie objęto techników farmaceutycznych z uwagi na prawnie ograniczony zakres obowiązków niedający technikom uprawnień do sprawowania opieki farmaceutycznej. Wyniki badania nie są reprezentatywne, należy do nich podchodzić z dużą ostrożnością. 
Do analizy współzależności opinii zastosowano miarę statystyczną, współczynnik zbieżności Cramera $\mathrm{C}_{\mathrm{xy}}$, oparty na tablicy korelacyjnej oraz na empirycznej wartości statystyki chi-kwadrat $\left(\chi^{2}\right)$ skorygowanej poprawką Yatesa. Z właściwości współczynnika zbieżności Cramera wynika, że stosowanie tej miary do analizy korelacji pociąga za sobą konieczność oceny statystycznej istotności wyniku pomiarowego, która może być dokonana tylko pośrednio i w drodze weryfikacji hipotezy zerowej o stochastycznej niezależności obserwowanych zmiennych losowych za pomocą testu zgodności Pearsona wykorzystującego standaryzowaną zmienną losową chi-kwadrat. Odrzucenie tej hipotezy pozwala traktować korelację obu zmiennych w sposób statystycznie znaczący (nieprzypadkowy). Należy przy tym podkreślić, że tylko w przypadku zdecydowanego odrzucenia hipotezy zerowej o stochastycznej niezależności obserwowanych zmiennych dalsza kontynuacja analizy korelacyjnej (zastosowanie współczynnika Cramera) znajduje uzasadnienie merytoryczne (Luszniewicz i Słaby, 2008, 280). Do określenia siły zależności korelacyjnej przyjęto następującą skalę (Dancey i Reidy, 2011,176):

- 0 - zależność zerowa (brak zależności),

— 0,1-0,3 - zależność słaba (niska),

— 0,4-0,6 — zależność umiarkowana (,zauważalna”),

- 0,7-0,9-zależność silna,

— 1,0 — zależność bardzo silna (doskonała).

\subsection{Wyniki i wnioski z przeprowadzonego badania empirycznego}

$\mathrm{Na}$ istnienie barier wdrażania opieki farmaceutycznej w praktyce aptecznej wskazuje stan opieki farmaceutycznej w Polsce. Stanowią one naturalny przejaw oporu wobec niewłaściwie zaprojektowanych i wprowadzonych zmian systemu świadczenia usług farmaceutycznych. Wprowadzenie legalnej definicji opieki farmaceutycznej do systemu polskiego prawa farmaceutycznego bez wsparcia w postaci szczegółowych przepisów wykonawczych, przy jednoczesnym braku efektywnej kampanii promocyjnej wśród pacjentów, lekarzy i farmaceutów, skutkowało brakiem zainteresowania wymienionych przedstawicieli zawodów medycznych w partycypacji świadczenia przedmiotowej usługi farmaceutycznej. Szczegółowo bariery wdrożenia opieki farmaceutycznej przedstawiono w tabeli 2.

Dokonując oceny wyników badania empirycznego, należy zauważyć, że do najczęściej identyfikowanych barier wdrożenia opieki farmaceutycznej zalicza się brak precyzyjnych regulacji prawnych (wskazanych przez $80,2 \%$ farmaceutów) oraz brak wymiernych korzyści dla apteki (wskazanych przez 78,4\% aptekarzy). Farmaceuci obawiają się, że wzrost uprawnień i odpowiedzialności przy nieprecyzyjnym systemie prawa farmaceutycznego może skutkować narażeniem na konsekwencje karne i sankcje odszkodowawcze. Dodatkowo w obecnym otoczeniu prawnym i ekonomicznym sprawowanie opieki farmaceutycznej 
Tabela 2. Bariery wdrożenia opieki farmaceutycznej w aptece ogólnodostępnej według farmaceutów

\begin{tabular}{|c|c|c|c|c|c|}
\hline \multirow{3}{*}{$\begin{array}{l}\text { Bariery wdrożenia opieki farmaceutycznej } \\
\text { w aptece ogólnodostępnej }\end{array}$} & \multicolumn{2}{|c|}{$\begin{array}{l}\text { Apteki } \\
(\mathrm{n}=111)\end{array}$} & \multicolumn{3}{|c|}{$\begin{array}{c}\text { Współzależność } \\
\text { od rodzaju wykształcenia } \\
\text { właściciela apteki }\end{array}$} \\
\hline & \multirow[t]{2}{*}{$\sum$} & \multirow[t]{2}{*}{$\%$} & \multirow{2}{*}{$\begin{array}{c}\mathrm{F} \\
\text { Tak } \\
\text { Nie }\end{array}$} & \multirow{2}{*}{$\begin{array}{l}\text { NF } \\
\text { Tak } \\
\text { Nie }\end{array}$} & $\chi_{\text {Yates }}^{2}$ \\
\hline & & & & & $\mathrm{C}_{\mathrm{xy}}$ \\
\hline \multirow[t]{2}{*}{ brak precyzyjnych regulacji prawnych } & 89 & 80,2 & 45 & 44 & 2,9716 \\
\hline & & & 6 & 16 & $\mathrm{~B} / 0,16^{*}$ \\
\hline \multirow[t]{2}{*}{ brak wymiernych korzyści dla apteki } & 87 & 78,4 & 40 & 47 & 0,0479 \\
\hline & & & 11 & 13 & B \\
\hline \multirow[t]{2}{*}{ brak dostatecznej ilości czasu dla pacjenta } & 66 & 59,5 & 31 & 35 & 0,0046 \\
\hline & & & 20 & 25 & B \\
\hline \multirow[t]{2}{*}{ brak zainteresowania pacjenta } & 65 & 58,6 & 32 & 33 & 0,3997 \\
\hline & & & 19 & 27 & $\mathrm{~B}$ \\
\hline \multirow[t]{2}{*}{$\begin{array}{l}\text { brak promocji opieki farmaceutycznej } \\
\text { wśród pacjentów }\end{array}$} & 63 & 56,8 & 31 & 32 & 0,3569 \\
\hline & & & 20 & 28 & $\mathrm{~B}$ \\
\hline \multirow[t]{2}{*}{$\begin{array}{l}\text { brak możliwości efektywnej współpracy } \\
\text { z środowiskiem lekarzy }\end{array}$} & 61 & 55,0 & 31 & 30 & 0,8962 \\
\hline & & & 20 & 30 & $\mathrm{~B}$ \\
\hline \multirow[t]{2}{*}{$\begin{array}{l}\text { brak wspólnego zintegrowanego systemu } \\
\text { informatycznego na linii aptekarz-lekarz }\end{array}$} & 57 & 51,4 & 25 & 32 & 0,0690 \\
\hline & & & 26 & 28 & B \\
\hline \multirow[t]{2}{*}{ zbyt duże koszty dla apteki } & 44 & 39,6 & 19 & 25 & 0,0778 \\
\hline & & & 32 & 35 & $\mathrm{~B}$ \\
\hline \multirow[t]{2}{*}{$\begin{array}{l}\text { zbyt duży zakres dodatkowych } \\
\text { obowiązków dla farmaceuty }\end{array}$} & 32 & 28,8 & 15 & 17 & 0,0073 \\
\hline & & & 36 & 43 & $\mathrm{~B}$ \\
\hline \multirow[t]{2}{*}{$\begin{array}{l}\text { brak odpowiedniego przygotowania } \\
\text { farmaceuty }\end{array}$} & 25 & 22,5 & 11 & 14 & 0,0004 \\
\hline & & & 40 & 46 & B \\
\hline \multirow[t]{2}{*}{ brak stanowiska konsultacyjnego $\mathrm{w}$ aptece } & 21 & 18,9 & 9 & 12 & 0,0052 \\
\hline & & & 42 & 48 & $\mathrm{~B}$ \\
\hline \multirow[t]{2}{*}{$\begin{array}{l}\text { negatywne nastawienie lekarzy } \\
\text { do współpracy }\end{array}$} & 19 & 17,1 & 9 & 10 & 0,0135 \\
\hline & & & 42 & 50 & B \\
\hline
\end{tabular}

Uwagi: $\sum$ — liczba aptek, \% — odsetek aptek, F — liczba aptek, w których właścicielem jest farmaceuta, NF — liczba aptek, których właścicielem nie jest farmaceuta, TAK = zdecydowanie tak + raczej tak, NIE $=$ nie wiem + raczej nie + zdecydowanie nie, $=3,8415,=2,7055, \mathrm{~B}-$ brak statystycznie istotnej zależności pomiędzy zmiennymi X i Y (wartość < ) *decyzja niejednoznaczna: przy innym, akceptowalnym teoretycznie poziomie istotności $=0,1$, wartość $=2,7055$; dla zależność korelacyjna jest istotna.

Źródło: opracowanie na podstawie badań własnych.

Ekonomia - Wroclaw Economic Review 24/4 (2018)

(C) for this edition by CNS 
przy braku zainteresowania ze strony pacjenta nie gwarantuje aptece wymiernych korzyści. Niskie marże detaliczne oraz wysokie koszty stałe obejmujące między innymi czynsz za wynajem lokalu oraz koszty personelu fachowego wymagają odpowiedniej liczby klientów, którzy zapewniliby aptece należyty poziom przychodów ze sprzedaży. Konieczność poświęcenia dodatkowego czasu dla pacjenta może wpłynąć na spadek liczby klientów obsługiwanych w tym samym czasie. Pacjent lubi być zauważalny i nie lubi stać zbyt długo w kolejce, stąd właściwe sprawowanie opieki farmaceutycznej może wymagać zatrudnienia dodatkowego pracownika, co podnosi poziom kosztów funkcjonowania apteki i może uczynić działalność mniej opłacalną. Brak dostatecznej ilości czasu dla pacjenta (wskazany przez 59,5\% farmaceutów) wynika ze złej organizacji stanowisk w izbie ekspedycyjnej, która może być pochodną zbyt małej obsady kadrowej. Często zdarza się, że farmaceuci, zwłaszcza zatrudnieni w tak zwanych aptekach sieciowych, mają odgórnie narzucony limit czasu, który mogą poświęcić obsłudze jednego pacjenta, i są z tego przez menedżerów i właścicieli rygorystycznie rozliczani. Wdrażanie opieki farmaceutycznej w takich warunkach może powodować opór fachowego personelu apteki. Brak zainteresowania pacjenta usługą opieki farmaceutycznej (wskazany przez 58,6\% farmaceutów) wynika z niewiedzy pacjentów spowodowanej brakiem jakiejkolwiek kampanii informacyjnej. Pacjenci często nie wiedzą, czym jest opieka farmaceutyczna, przez co nie są świadomi korzyści, jakie mogą otrzymać, uczestnicząc w poszczególnych jej programach.

Istotną przeszkodą $\mathrm{w}$ implementacji opieki farmaceutycznej jest brak możliwości efektywnej współpracy ze środowiskiem lekarzy (wskazany przez 55\% farmaceutów), który wynika z braku zintegrowanego systemu informatycznego na linii aptekarz-lekarz. Utrudnia to farmaceucie efektywny nadzór nad procesem farmakoterapii pacjenta, zwłaszcza gdy pojawią się wątpliwości dotyczące czytelności recepty bądź zasadności dawkowania leku, a kontakt telefoniczny z lekarzem jest czysto teoretyczny. Znamienne jest również, że 17,1\% farmaceutów wskazuje na negatywne nastawienie lekarzy do współpracy. Taka postawa lekarzy może wynikać z braku stosownych regulacji prawnych. W obecnym systemie politycznoprawnym to właśnie lekarz jest odpowiedzialny za zarządzanie farmakoterapią pacjenta. System prawa medycznego i farmaceutycznego nie zawiera regulacji umożliwiających precyzyjne rozgraniczenie odpowiedzialności za proces farmakoterapii pacjenta. Negatywne nastawienie lekarzy do współpracy z aptekarzami w ramach sprawowania opieki farmaceutycznej może również wynikać z braku odpowiedniej ilości czasu i wcale nie musi brać się z niechęci, zwłaszcza gdy weźmie sie pod uwagę, że duża część placówek medycznych zmaga się z brakami kadrowymi.

Bariery wdrażania opieki farmaceutycznej w praktyce aptecznej wynikają również z braku odpowiedniego przygotowania farmaceuty, na co wskazuje $22,5 \%$ aptekarzy, oraz braku możliwości wydzielenia powierzchni na stanowisko konsultacyjne (18,9\% wskazań farmaceutów). Jak słusznie utrzymuje J. Łazowski: 
miejsce, które można nazwać stanowiskiem konsultacyjnym, ma dla opieki farmaceutycznej podstawowe i trudne do przecenienia znaczenie, gdyż ułatwia stworzenie atmosfery prywatności i profesjonalizmu, a tym samym uświadamia ludziom, że w aptece świadczone są usługi opieki zdrowotnej. (Łazowski, 2005b, s. 7)

Brak możliwości zapewnienia poufności kontaktu pacjenta z farmaceutą wyklucza w praktyce sprawowanie opieki farmaceutycznej w aptece.

Dokonując oceny wyników badania empirycznego pod względem przeprowadzonej analizy statystycznej, należy zauważyć, że występowanie barier wdrażania opieki farmaceutycznej nie jest uzależnione od tego, czy właściciel apteki jest farmaceutą, czy też nie. Można tak przyjąć już na etapie weryfikacji hipotezy zerowej, albowiem na poziomie istotności $=0,05$ wartości empiryczne $\chi^{2}$ mieściły się w przedziale nieodrzuceń. Mając na uwadze, że analiza korelacyjna jest merytorycznie uzasadniona wyłącznie w wypadku zdecydowanego odrzucenia hipotezy zerowej o stochastycznej niezależności obserwowanych zmiennych, to na podstawie zebranych danych należy zauważyć, że statystyczna zależność zmiennych $X$ - występowanie zjawiska (potwierdzenie występowania zjawiska - TAK, negacja zjawiska - NIE) i $Y$ - posiadane wykształcenie właściciela apteki (farmaceuta vs nie-farmaceuta) jest nieistotna (korelacja nie występuje) ${ }^{8}$.

\section{Podsumowanie}

Efektywne sprawowanie opieki farmaceutycznej w aptece ogólnodostępnej stanowi duże wyzwanie dla farmaceuty, ponieważ wymaga podjęcia wielu działań związanych z reorganizacją procesu świadczenia usług farmaceutycznych. Najtrudniej jest dokonać zmian w mentalności personelu fachowego, aby przekonać pracowników do nowych obowiązków i zadań, co można osiągnąć poprzez powiązanie z systemem motywacyjnym. Istotne jest również przekonanie właściciela apteki do konieczności poniesienia dodatkowych wydatków na stworzenie stanowiska (punktu) konsultacyjnego w celu zapewnienia miejsca do swobodnej rozmowy z pacjentem według poniższych zasad (Łazowski, 2005b, 7-8):

— usytuowanie w izbie ekspedycyjnej jako miejscu łatwo dostępnym dla pacjenta i farmaceuty,

- usytuowanie na uboczu głównych szlaków komunikacyjnych izby ekspedycyjnej: wejście — miejsce dyspensowania — kasa — wyjście,

8 W przypadku kategorii „brak precyzyjnych regulacji prawnych” decyzja jest niejednoznaczna, albowiem przy innym, akceptowalnym teoretycznie poziomie istotności $=0,1$, wartość $=2,7055$. $\mathrm{Dla}=2,9716$ i należącego do przedziału zależność korelacyjna jest istotna. Stosując współczynnik zbieżności Cramera zauważyć należy, że wartość na poziomie 0,16 świadczy o niskiej sile korelacji zmiennych $X, Y$. 
— wizualizacja otoczenia eksponująca wymiar medyczny apteki — placówki ochrony zdrowia publicznego, w której świadczone są usługi farmaceutyczne,

— zapewnienie podstawowego wyposażenia stanowiska/punktu konsultacyjnego: niski stolik i co najmniej dwa „wygodne” krzesła (należy przewidzieć możliwość udziału w rozmowie małżonki/a lub opiekuna pacjenta) oraz sprzęt i materiały informacyjne (pomocnicze), z których może korzystać farmaceuta prowadzący konsultacje,

— oddzielenie od siebie każdego stanowiska w przypadku tworzenia kilku stanowisk/punktów konsultacyjnych,

- oznakowanie każdego stanowiska/punktu konsultacyjnego jako miejsca przeznaczonego do prywatnych rozmów pacjenta $\mathrm{z}$ farmaceutą,

- wydzielenie w pobliżu stanowiska/punktu konsultacyjnego miejsca dla oczekujących na swoją kolej pacjentów, wyposażonego w „wygodne” krzesła i materiały informacyjne (w większych aptekach).

Bariery wdrażania opieki farmaceutycznej wynikające z czynników zarówno zewnętrznych (nieprecyzyjny system prawa farmaceutycznego, brak wymiernych korzyści dla apteki i kampanii promocyjnej skierowanej do pacjenta, lekarza i farmaceuty), jak i wewnętrznych (brak stanowiska konsultacyjnego i właściwego przygotowania farmaceuty) mogą zostać wyeliminowane w wyniku zastosowania wieloetapowych i wielopoziomowych działań przez następujące organy, instytucje i przedstawicieli zawodu:

1. władze polityczne

— kompleksowe ujęcie opieki farmaceutycznej w systemie prawa farmaceutycznego poprzez określenie definicji, celów i charakterystyki poszczególnych programów oraz precyzyjnego zdefiniowania zakresów obowiązków i poziomów odpowiedzialności poszczególnych przedstawicieli zawodów medycznych, jak też zasad gromadzenia, przechowywania i udostępniania bazy pacjentów,

— określenie zasad współpracy farmaceuty z przedstawicielami poszczególnych zawodów medycznych w zakresie efektywnego sprawowania opieki farmaceutycznej,

— opracowanie systemu monitorowania efektów opieki farmaceutycznej oraz efektywnych mechanizmów kontroli,

— opracowanie systemu zachęt dla aptekarzy (zarówno dla właścicieli aptek, jak i jej pracowników);

2. ośrodki naukowe

— zwiększenie nacisku na jakość kształcenia w zakresie efektywnej realizacji opieki farmaceutycznej w oparciu o poszczególne jej programy,

— popularyzacja korzyści opieki farmaceutycznej;

3. organy nadzoru farmaceutycznego i samorząd zawodu aptekarskiego

- popularyzacja opieki farmaceutycznej wśród farmaceutów i lekarzy,

— promocja opieki farmaceutycznej wśród pacjentów, 
- opracowanie efektywnych procedur kontrolnych (zorientowanych na efektywność) oraz popularyzacja zachowań proetycznych;

4. właściciele aptek

- stworzenie w miejscu pracy warunków do efektywnego sprawowania opieki farmaceutycznej (wydzielenie powierzchni na stanowisko konsultacyjne, stworzenie profesjonalnego punktu konsultacyjnego, zapewnienie odpowiedniej obsady kadrowej),

— dbanie o to, aby czynności zastrzeżone dla aptekarza były wykonywane wyłącznie przez osoby uprawnione,

— popularyzowanie opieki farmaceutycznej wśród personelu apteki;

5. farmaceuci aptekarze

- aktywny udział w poszczególnych programach opieki farmaceutycznej,

- udzielanie porad i konsultacji w zgodzie ze swoim sumieniem i współczesną wiedzą medyczną, kierując się dobrem pacjenta ze zrozumieniem odpowiedzialności za jego zdrowie i życie,

- samodoskonalenie umiejętności zawodowych.

Efektywna implementacja opieki farmaceutycznej w praktyce aptecznej powinna opierać się na wskazywaniu zalet i korzyści, jakie otrzymają pacjent, farmaceuta i właściciel apteki. Postępowanie farmaceuty zorientowane na wykrycie i rozwiązanie problemów lekowych, aby według ustalonego planu właściwie zdefiniować cele i przyjąć optymalne rozwiązanie terapeutyczne, pozwoli zamienić profesjonalne doradztwo w efektywny proces opieki farmaceutycznej.

\section{Bibliografia}

Adamczyk J. (2016), Marketing i reklama apteki, [w:] Meritum prawo farmaceutyczne, red. M. Krekora, J. Adamczyk, Warszawa, s. 246-368.

Brooks J.M., Klepser D.G., Urmie J.M., Farris K.B., Doucette W.R. (2007), Effect of Local Competition on the Willingness of Community Pharmacies to Supply Medication Therapy Management Services, „Journal of Health and Human Services Administration” 30, nr 1, s. 4-27.

Dancey C.P., Reidy J. (2011), Statistics without Maths for Psychology, Harlow.

Główny Urząd Statystyczny (2017), Apteki i punkty apteczne w 2016 r., notatka informacyjna z dnia 25.07.2017, http://stat.gov.pl/obszary-tematyczne/zdrowie/zdrowie/apteki-i-punktyapteczne-w-2016-r-,15,1.html (dostęp: 27.11.2017).

Komunikat Głównego Inspektora Farmaceutycznego nr 2/2013 z dnia 8 kwietnia 2013 roku w sprawie publikacji prasowych dotyczących zakazu reklamy aptek, https://www.gif.gov.pl/pl/decyzje-i-komunikaty/komunikaty/365,Komunikat-Glownego-Inspektora-Farmaceutycznego-Nr-22013-z-dnia-8-kwietnia-2013r-.html (dostęp: 25.03.2018).

Luszniewicz A., Słaby T. (2008), Statystyka z pakietem komputerowym STATISTICA PL. Teoria $i$ zastosowania, Warszawa.

Łazowski J. (2005a), Podstawy opieki farmaceutycznej w teorii i praktyce aptecznej, Warszawa.

Łazowski J. (2005b), Skuteczne wdrażanie opieki farmaceutycznej do praktyki aptek ogólnodostępnych, [w:] Opieka farmaceutyczna w prawie i praktyce, red. J. Brandys, Warszawa.

Marczak J.T. (2007), Strategia wdrażania opieki farmaceutycznej, „Biuletyn Naczelnej Rady Aptekarskiej" 6 (17), s. 1-12.

Ekonomia - Wroclaw Economic Review 24/4 (2018)

(C) for this edition by CNS 
Rozporządzenie Parlamentu Europejskiego i Rady (UE) 2016/679 z dnia 27 kwietnia 2016 roku w sprawie ochrony osób fizycznych w związku z przetwarzaniem danych osobowych i w sprawie swobodnego przepływu takich danych oraz uchylenia dyrektywy 95/46/WE (ogólne rozporządzenie o ochronie danych) (Tekst mający znaczenie dla EOG), Dz.Urz.UE z 4 maja 2016 r., L119/1.

Scharitzer D., Kollarits H.C. (2000), Satisfied Customers: Profitable Customer Relationships: Pharmaceutical Marketing: How Pharmaceutical Sales Representatives Can Achieve Economic Success Through Relationship Management With Settled General Practitioners - An Empirical Study, „Total Quality Management \& Business Excellence” 11, nr 7, s. 955-965.

Skowron A. (2005), Proces opieki farmaceutycznej, [w:] Opieka farmaceutyczna w prawie i praktyce, red. J. Brandys, Warszawa.

Skowron A. (2008), Opieka farmaceutyczna - jak zaczać??, „Aptekarz Polski. Pismo Naczelnej Izby Aptekarskie" 27, nr 5e, s. 6-7.

Skowron A., Polak W., Polak S., Polak M. (2010), Dokumentowanie opieki farmaceutycznej z wykorzystaniem bazy FONTIC, „Farmacja Polska” 66, nr 6, s. 393-402.

Szalonka K. (2011), Opieka farmaceutyczna w ochronie zdrowia Polaków, Warszawa.

Ustawa z dnia 19 kwietnia 1991 roku o izbach aptekarskich, Dz.U. z 1991 r. Nr 41, poz. 179 ze zm.

Ustawa z dnia 29 sierpnia 1997 roku o ochronie danych osobowych, Dz.U. z 1997 r. Nr 133, poz. 883 ze zm.

Ustawa z dnia 10 stycznia 2008 roku o zmianie ustawy o izbach aptekarskich, Dz.U. z 2008 r. Nr 47, poz. 273.

Żak K. (2011), Perspektywy rozwoju rynku aptecznego w Polsce, „Studia i Prace Kolegium Zarządzania i Finansów. Zeszyt Naukowy" 112, s. 146-161.

Żak K. (2017), Implementacja programu opieki farmaceutycznej w aptece ogólnodostępnej — dostosowanie do potrzeb osób niepetnosprawnych, „Ekonomia - Wroclaw Economic Review” 23, nr 1, s. 83-103.

Żak K. (2018), Realizacja celów komercyjnych a społeczna misja apteki ogólnodostępnej — konflikt pomiędzy etyka a biznesem jako źródto występowania zjawisk patologicznych na aptecznym rynku farmaceutycznym, „Prakseologia” 160, s. 132-150. 